\title{
The millipede Eudasypeltis setosus (Pocock, 1894) new to the fauna of Thailand (Diplopoda: Polydesmida: Paradoxosomatidae)
}

\section{Аиплопода Eudasypeltis setosus (Pocock, 1894), новая дмя фауны Таиланда (Diplopoda: Polydesmida: Paradoxosomatidae)}

\author{
N. Likhitrakarn ${ }^{1}$, S.I. Golovatch ${ }^{2} \&$ S. Panha ${ }^{1}$ \\ Н. Аикиртракарн ${ }^{1}$, С.И. Головач ${ }^{2}$, С. Панха ${ }^{1}$ \\ ${ }^{1}$ Animal Systematics Research Unit, Department of Biology, Faculty of Science, Chulalongkorn University, Bangkok 10330 Thailand.
${ }^{2}$ Институт проблем жкологии и эволюции РАН, Ленинский пр-т, 33, Москва 119071 Россия.
${ }^{2}$ Institute for Problems of Ecology and Evolution, Russian Academy of Sciences, Leninsky pr. 33, Moscow 119071 Russia.
}

KEY WORDS: millipede, taxonomy, new record, Thailand.

КЛЮЧЕВЫЕ СЛОВА: диплопода, таксономия, новая находка, Таиланд.

ABSTRACT. A second record of the millipede $E u$ dasypeltis setosus (Pocock, 1894), previously known from a poorly preserved holotype from Owen Island, Mergui Archipelago, Myanmar, is given. This species is also redescribed and abundantly illustrated, based on fresh samples taken from Similan Island, Andaman Sea, Thailand.

РЕЗЮМЕ. Представлена новая находка диплоподы Eudasypeltis setosus (Pocock, 1894), прежде известной только по плохо сохранившемуся голотипу с острова Оуэн (архипелаг Мергуи, Мьянма). Этот вид подробно переописан и снабжен многочисленными иллюстрациями на основе нового материала, собранного на острове Симилан (Андаманское море, Таиланд).

\section{Introduction}

Eudasypeltis Pocock, 1895 is a small genus of the tribe Orthomorphini easily distinguished superficially by the extremely densely and irregularly granulate and pubescent metaterga, coupled with the rather poorly developed paraterga. As regards its gonopod structure, the femorite is rather stout to slender, simple, only slightly enlarged distally, devoid of any traces of torsion, carrying the seminal groove solely on the mesal side, set off by a distinct demarcation cingulum from a long, mesally directed, clearly subacuminate solenophore which sheathes the entire flagelliform solenomere [Golovatch, 1996, 1997].

Eudasypeltis currently contains only two species, both rather recently redescribed from type material [Golovatch, 1996]: E. setosus (Pocock, 1895), from Owen Island, Mergui Archipelago, Myanmar, and E. pusillus Pocock, 1895 (the type-species), from the Tanintharyi, or Tenasserim, region, mainland Myanmar.
The male holotype of E. setosus, housed in the Natural History Museum, London, is in very poor condition, incomplete (the head and body segments 1-4 missing), and very greasy. The body segments are entirely greenish due to pin corrosion, because the specimen had been pinned before transferred to alcohol [Golovatch, 1996].

The present paper not only puts on record E. setosus as a species new to the fauna of Thailand, but also provides its proper, abundantly illustrated redescription as based on fresh samples taken on Similan Island, Andaman Sea, Thailand. The first information concerning the habitat of this species becomes available as well.

\section{Material and methods}

Material was preserved in $75 \%$ ethanol and studied in the lab using a standard Olympus stereomicroscope. Scanning electron micrographs (SEM) were taken using a JEOL, JSM-5410 LV microscope. After SEM examination of the gonopods, they were returned to alcohol. At present, the entire material serving as the basis for the present contribution is deposited in the collection of the Museum of Zoology of Chulalongkorn University. Live coloration was photographed in the field.

\section{Systematics}

Eudasypeltis setosus (Pocock, 1894)

Figs 1-4.

Strongylosoma setosum Pocock, 1894: 320.

Eudasypeltis setosus — Pocock, 1895: 797; Attems, 1937: 149; Golovatch, 1995: 73.

MATERIAL. 1 \%', 3 우, Thailand, Phang Nga Province, Khura Buri District, Similan National Park, Island 6, 8³5'19.80"N, 97³8'20.50"E, 6.04.2010, leg. S. Panha, C. Sutcharit \& N. Likhitrakarn. 


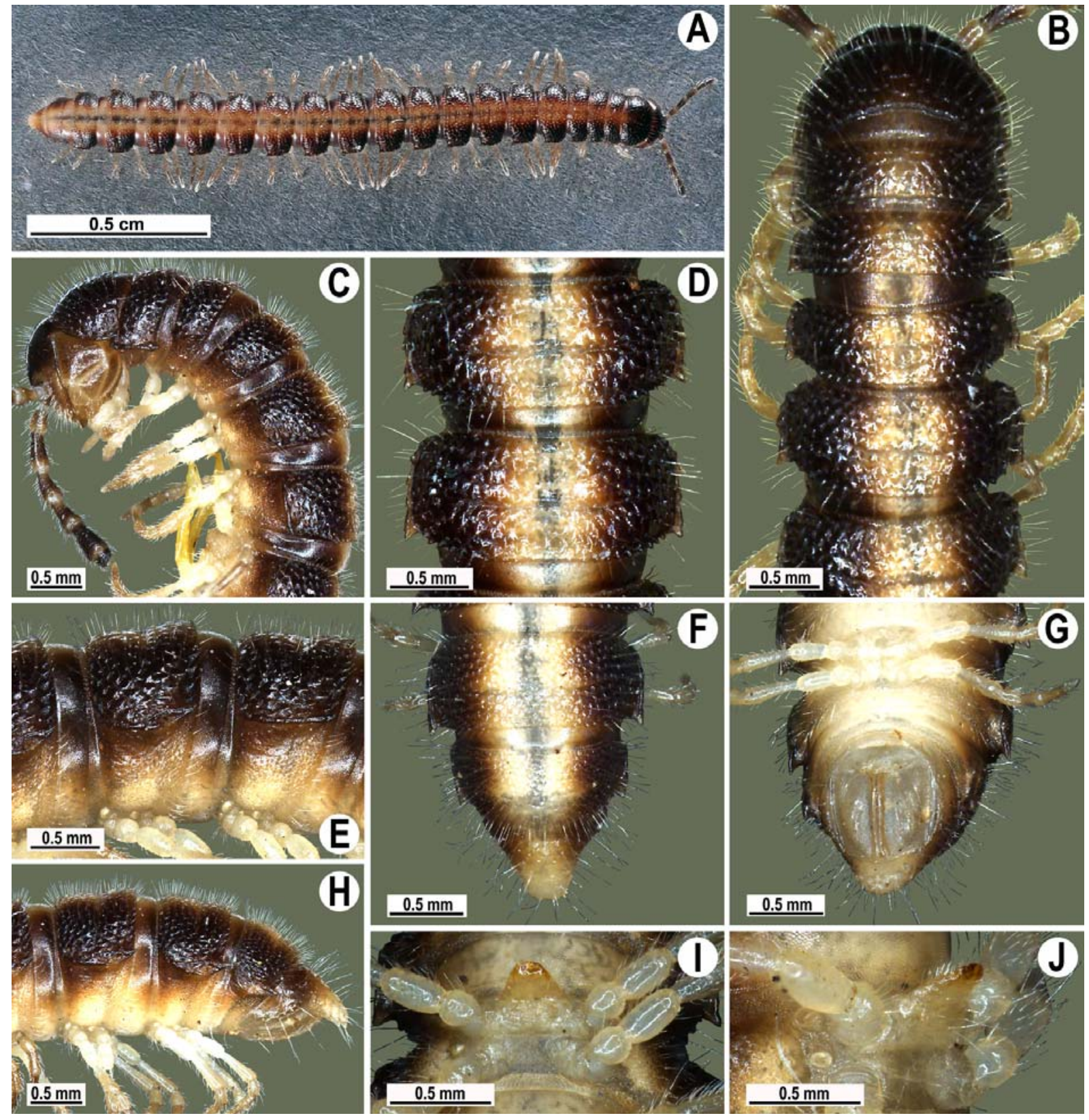

Fig. 1. Eudasypeltis setosus (Pocock, 1894), $0^{7}$ from Similan Island: A — habitus, live coloration; B \& C — anterior part of body, dorsal and lateral views, respectively; D \& E - segments 10 and 11, dorsal and lateral views, respectively; F-H — posterior part of body, lateral, dorsal and ventral views, respectively; I \& J - sternal lobe between coxae 4, subcaudal and sublateral views, respectively.

Рис. 1. Eudasypeltis setosus (Pocock, 1894), О7 с острова Симилан: А — габитус, прижизненная окраска; В, С — передняя часть тела, соответственно сверху и сбоку; D, E - сегменты 10 и 11, соответственно сверху и сбоку; F-H - задняя часть тела, соответственно сбоку, сверху и снизу; I, J - стернальная планстина между тазиками 4, соответственно почти сзади и почти сбоку.

DIAGNOSIS. Differs from E. pusillus, the only congener, in the hypoproct being subtrapeziform (versus triangular), the $\sigma^{7}$ postgonopodal sterna supplied with a vestigial cone located near the rear coxa (versus unmodified), and the gonopod femorite slender and long (versus stouter and shorter) etc. (see also Key below).

DESCRIPTION. Length $17.5 \mathrm{~mm}\left(\mathrm{O}^{7}\right), 18.8-21.3$ $\mathrm{mm}(+)$, width of midbody pro- and metazona 1.35 and $2.0 \mathrm{~mm}\left(\mathrm{O}^{\mathrm{T}}\right), 1.83-1.9$ and $2.33-2.4 \mathrm{~mm}(+)$, respectively.
Live coloration retained in alcohol (Figs 1A-J), dark brown, starting from metaterga 2 with a pattern of a paramedian pair of contrastingly whitish to yellow, wide, dorsal stripes (only slightly infuscate in vivo, Fig. 1A) interrupted by a narrow, dark, axial line; antennae, legs and epiproct grey-brownish, venter and basal podomeres white-yellowish.

Head extremely densely setose; vertex rather smooth, shagreened and slightly rugulose; epicranial 


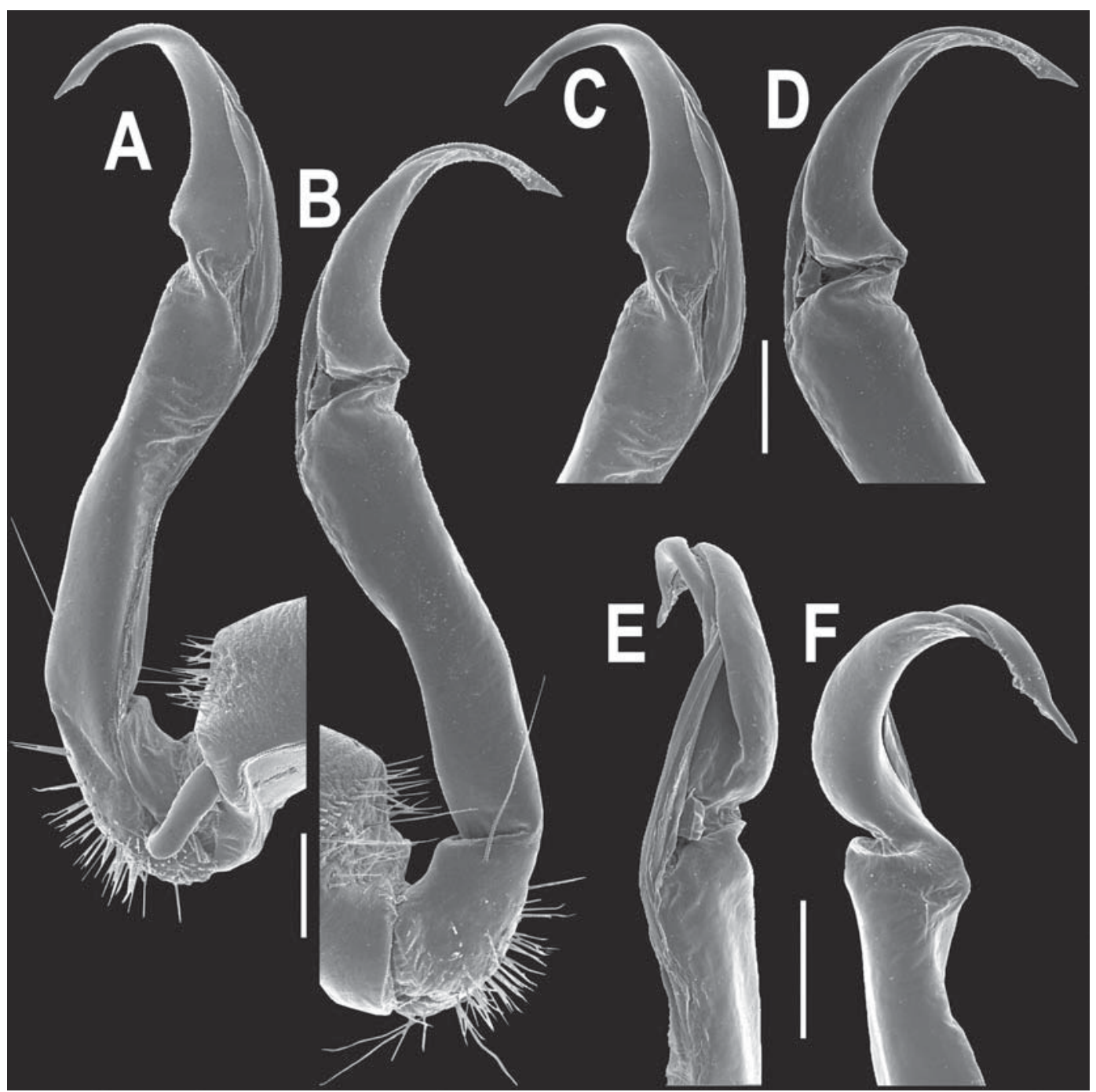

Fig. 2. Eudasypeltis setosus (Pocock, 1894), O from Similan Island: A \& B — right gonopod, mesal and lateral views, respectively; $\mathrm{C}-\mathrm{F}$ - distal part of right gonopod, mesal, lateral, subcaudal and suboral views, respectively. Scale bar: $0.2 \mathrm{~mm}$.

Рис. Eudasypeltis setosus (Pocock, 1894), О’ с острова Симилан: А, В - правый гонопод, соответственно изнутри и сбоку; $\mathrm{C}-\mathrm{F}$ - дистальная часть правого гонопода, соотвественно изнутри, сбоку, почти сзади и почти спереди. Масштаб: 0,2 мм.

suture distinct. Antennae moderately long, clavate (antennomere 7 broadest) (Figs 1A, C), reaching behind body segment $3\left(\mathrm{O}^{7}\right)$ or $2(+)$ dorsally.

Head in width $<$ collum $<$ segment $3<$ segments 2 and $4<$ segments $5-17$, thereafter body gently and gradually tapering. Collum with abundant, small, setiferous knobs; caudal corner of its paraterga very narrowly rounded, slightly bordered and declined ventrally, not surpassing rear tergal contour (Figs 1B, C).

Tegument mostly rough but shining, prozona very finely shagreened, metaterga roughly granululate-tuberculate and shagreened; surface below paraterga finely microgranulate. Metaterga with abundant, small, irregular, setiferous knobs, more evident ones at posterior edge of metaterga. Tergal setae long, slender, often abraded, about as long as 1/3 metaterga. Axial line very faint. barely traceable. Paraterga modestly developed (Figs 1A-H), usually slightly upturned to subhori- zontal, all lying well below dorsum (at about half of midbody height), anterior edge of paraterga very modestly developed, sides rounded, only anterior edge of segment 2 extended anteriorly and rounded, wingshaped, while its caudal corner narrowly rounded; thereafter caudal tip pointed, bent posteriad, not surpassing rear contour; paraterga very thin and narrow in lateral view, like blunt blades, slightly thicker on pore-bearing segments. Calluses delimited by a sulcus both dorsally and ventrally, with 2-6 evident lateral incisions, posterior edge slightly concave (Figs $1 \mathrm{~B}-\mathrm{H})$. Ozopores evident, dorsolateral, lying in an ovoid groove at about $3 / 4$ metazonital length. Transverse sulcus present on metaterga 5-18, usually narrow and superficial (especially so due to coarse texture around), line-shaped, not reaching bases of paraterga (Figs 1B-F, H). Stricture between pro- and metazona narrow, modestly ribbed at bottom down to bases of paraterga (Figs 1B-F, H). 

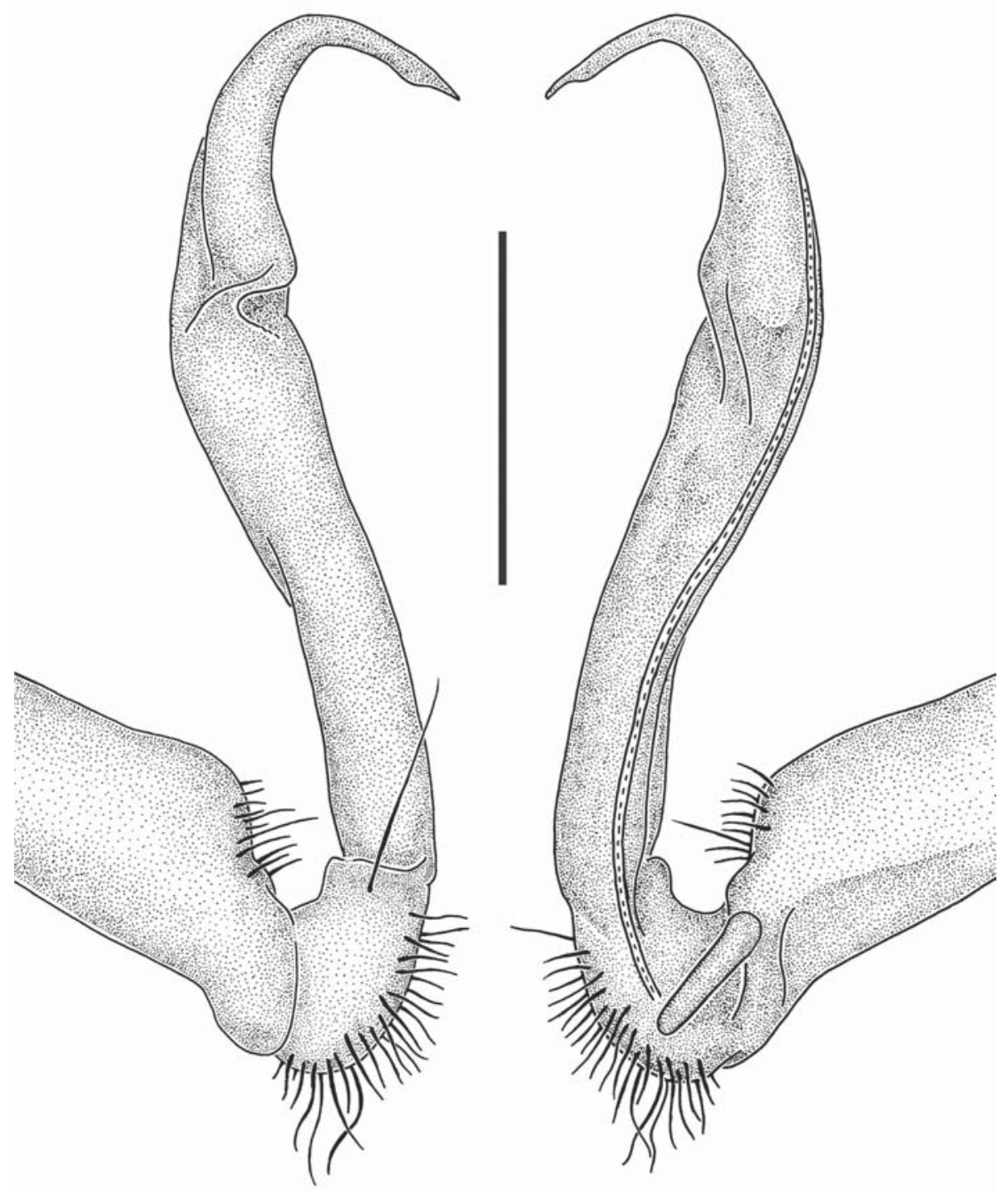

Fig. 3. Eudasypeltis setosus (Pocock, 1894), O’: A \& B — right gonopod, lateral and mesal views, respectively. Scale bar: 0.5 mm. Рис. Eudasypeltis setosus (Pocock, 1894), О’: А, В - правый гонопод, соответственно сбоку и изнутри. Масштаб: 0,5 мм.

Pleurosternal carinae traceable like a rather evident crest only on segment 2 , then either like a small caudal tubercle on segments 3-7 $\left(\mathrm{O}^{7}\right)$ (Fig. 1C) or on segment 3 alone ( 9 ). Epiproct (Figs $1 \mathrm{~F}-\mathrm{H})$ conical, flattened dorsoventrally, with two evident apical papillae and a faintly concave tip; preapical papillae evident. Hypoproct (Fig. 1G) subtriangular, setiferous knobs at caudal edge well-separated. Sterna delicately and sparsely setose, postgonopodal ones each with a vestigial cone only near rear coxa; lobe between $\sigma^{7}$ coxae 4 subtriangular, setose, high, conspicuous (Figs 1I, J). A pair of conspicuous, rounded, densely setose bulges flanking anterior edge of gonopod aperture. Legs rather short and slender, slightly incrassate in $\sigma^{7}$, about $0.8-0.9$ $\left(\sigma^{7}\right)$ or $0.5-0.6$ times $(+)$ as long as midbody height; $\sigma^{7}$ prefemora without modifications; $\sigma^{7}$ tarsi densely setose ventrally, but forming no evident brushes.
Gonopods (Figs 2, 3) simple. Coxa long and slender, with several setae distoventrally. Prefemur as usual, densely setose, less than 1/2 length of femorite. Latter slender, slightly curved and enlarged distad, postfemoral part not demarcated by a lateral sulcus. Solenophore simple, directed mesad, tip subacuminate, entirely sheathing a long flagelliform solenomere.

DISTRIBUTION. Owen Island, Myanmar; Similan Island, Thailand.

REMARKS. The distance between Owen (the type locality) and Similan islands is only about $300 \mathrm{~km}$. Our material fully agrees with the redescription of the holotype as given by Golovatch [1996], except for the slightly smaller size. Similan Island is covered with tropical rain forest, the average annual temperature being $27^{\circ} \mathrm{C}$ while the average air humidity $83 \%$ all the year round [MNPD, 2002]. There had been no rain for 


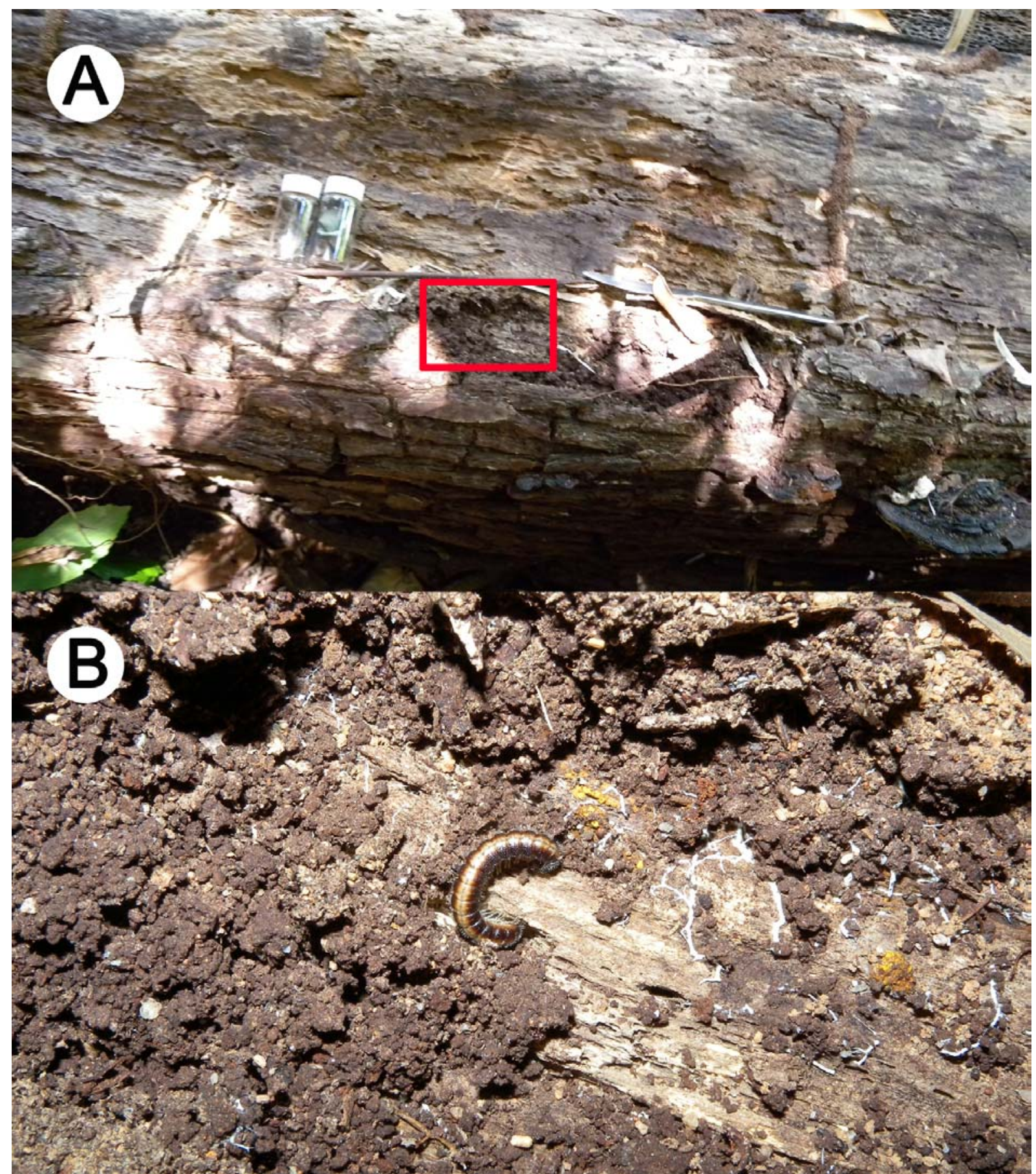

Fig. 4. Eudasypeltis setosus (Pocock, 1894): A \& B - habitat.

Рис. 4. Eudasypeltis setosus (Pocock, 1894): А, В - место обитания.

about two months when we collected the specimens. The millipedes were found under the bark of rotten logs, one or two in each of the logs (Fig. 4).

The following key can serve for separating both these congeners:

1. Pleurosternal carinae well-developed, at least until $\sigma^{7}$ segment 11 each with a caudal tooth. Gonopod femorite relatively stout
E. pusillus
- Pleurosternal carinae rather well-developed, at least until $\sigma^{7}$ segment 7 each with a caudal tooth. Gonopod femorite particularly slender (Figs 2, 3) ............... E. setosus

ACKNOWLEDGEMENTS. We would like to extend our deep gratitude to all collectors, mainly staff of the Animal Systematics Research Unit of the Chulalongkorn University, Bangkok. The first author is deeply obliged to the 
programme Strategic Scholarships for Frontier Research Network for the Joint Ph.D. Program Thai Doctoral degree from the Office of the Higher Education Commission, CHERG under the Limestone Biodiversity Project and the BRT Programme (TRF/BIOTECH Thailand Biodiversity Research and Training Programme) for their financial support.

We thank the staff of Similan Island Marine National Park, the Plant Genetic Conservation Project initiated by Her Royal Highness Princess Maha Chakri Sirindhorn and the Navy Special Warfare Unit of the Royal Thai Navy for providing us with considerable help and encouragement that made our fieldwork possible.

Special thanks go to Mrs Rujiporn Prateepasen, Chulalongkorn University Central Equipment Center, for skillfully taking SEM micrographs.

\section{References}

Attems C. 1937. Myriapoda 3. Polydesmoidea I. Fam. Strongylosomidae // Das Tierreich. Lfg.68. S.1-300.
Golovatch S.I. 1996. On several new or poorly-known Oriental Paradoxosomatidae (Diplopoda Polydesmida), IV // Arthropoda Selecta. Vol.4 (for 1995). Nos 3/4. P.71-78.

Golovatch S.I. 1997. On several new or poorly-known Oriental Paradoxosomatidae (Diplopoda Polydesmida), V // Ibid. Vol.5 (for 1996). Nos 3/4. P.131-141.

Pocock R.I. 1894. Supplementary notes on the Arachnida and Myriopoda of the Mergui Archipelago: with descriptions of some new species from Siam and Malaysia // J. Linn. Soc. Zool. Vol.24. P.316-326.

Pocock R.I. 1895. The Myriopoda of Burma, Pt. IV. Report upon the Polydesmoidea collected by Sig. L. Fea, Mr. K.W. Oates and others // Ann. Mus. Civ. Stor. Nat. Genoa, Ser.2. T.14. P.787-836.

MNPD 2002. Handbook of Marine National Park Tourism: Andaman Sea. Bangkok: Marine National Park Division, the Royal Forest Department. 24 pp.

Responsible editor K. Mikhailov 